\title{
Maastricht, medisch onderwijscentrum van de universe?
}

Citation for published version (APA):

Greep, J. M. (1992). Maastricht, medisch onderwijscentrum van de universe? kennis- en vaardighedentraining in internationaal perspectief. Maastricht University. https://doi.org/10.26481/spe.19920911cg

Document status and date:

Published: 11/09/1992

DOI:

$10.26481 / \mathrm{spe} .19920911 \mathrm{cg}$

Document Version:

Publisher's PDF, also known as Version of record

\section{Please check the document version of this publication:}

- A submitted manuscript is the version of the article upon submission and before peer-review. There can be important differences between the submitted version and the official published version of record.

People interested in the research are advised to contact the author for the final version of the publication, or visit the DOI to the publisher's website.

- The final author version and the galley proof are versions of the publication after peer review.

- The final published version features the final layout of the paper including the volume, issue and page numbers.

Link to publication

\footnotetext{
General rights rights.

- You may freely distribute the URL identifying the publication in the public portal. please follow below link for the End User Agreement:

www.umlib.nl/taverne-license

Take down policy

If you believe that this document breaches copyright please contact us at:

repository@maastrichtuniversity.nl

providing details and we will investigate your claim.
}

Copyright and moral rights for the publications made accessible in the public portal are retained by the authors and/or other copyright owners and it is a condition of accessing publications that users recognise and abide by the legal requirements associated with these

- Users may download and print one copy of any publication from the public portal for the purpose of private study or research.

- You may not further distribute the material or use it for any profit-making activity or commercial gain

If the publication is distributed under the terms of Article $25 \mathrm{fa}$ of the Dutch Copyright Act, indicated by the "Taverne" license above, 
Univers|teltsblbliotheek

Rijksuniversiteit Limburg

Postbus 616

6200 MD Maastricht

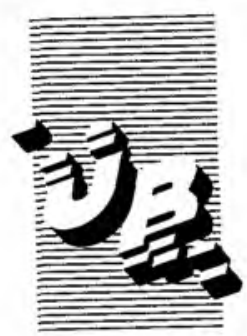

De uitleentermijn verstrijkt op:

\section{$02 \pi 0 \% .1992$}

Gelieve deze publicatie tijdig te retourneren of (telefonisch) verlenging van de uitleentermijn aan te vragen. 


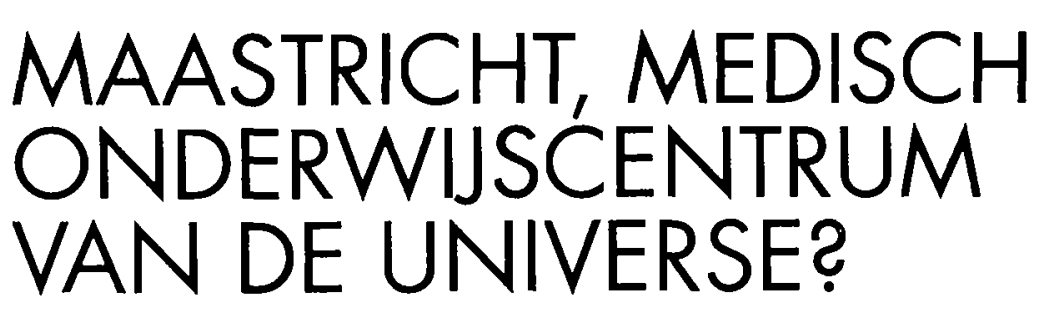

KENNIS- EN

VAARDIGHEDENTRAINING

IN INTERNATIONAAL

PERSPECTIEF

Afscheidsrede Prof.Dr. J.M. Greep, hoogleraar chirurgie

Rijksuniversiteit Limburg, Maastricht

11 september 1992 


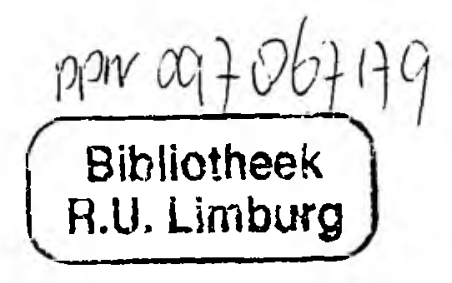


'We can only instil principles, put the student in the right path, give him methods, teach him how to study, and early to discern between essentials and non-essentials.'

Sir William Osler

'To admit once and for all the difficulty of learning medicine and the impossibility of teaching it.' A. Flexner 
Mijnheer de Rector Magnificus,

Leden van de Universitaire Gemeenschap,

Dames en Heren Studenten,

Geachte Toehoorders,

Negen januari 1981 had ik het voorrecht een Eredoctoraat uit te mogen reiken aan John Evans, de man die in 1969 het Probleem Gestuurd Onderwijs (PGO) in de praktijk bracht in McMaster, Hamilton, Ontario, Canada.

Toen de zeven 'founding fathers' in juni 1973 hun eerste vergadering in ons huis in Amsterdam hadden waren wij reeds op het spoor gezet van het Probleem Gestuurd Onderwijs door Tans die, na gesprekken met Wijnand Wijnen en Harmen Tiddens, ons attent maakte op McMaster. Wij creëerden snel een luchtbrug met Hamilton en makten de betrokken ambtenaren van het Ministerie van Onderwijs en Wetenschappen deelgenoot van onze eerste impressies.

\section{De start}

Het vierjarig post-college medisch onderwijssysteem in Canada vroeg om aanpassing naar de in praktisch de gehele wereld toegepaste post-high-school universitaire medische opleiding. In de kleine academische groep startten we met elkaar in een gelijkwaardige open relatie, waarin de capaciteiten van allen tot hun recht kwamen. Tiddens werd de eerste voorzitter van de kernstaf in augustus 1973 Zijn managementstijl was van groot belang, een teamwork bevorderende sfeer werd op niet Nederlandse wijze gecreëerd. Er ontstond een groep waarin wij allen aldoende onderdeel uitmaakten van het produktie- en leerproces. Na lange discussies, soms zelfs op Schiphol vlak voor een nieuwe tocht naar Canada, werd de matrix onderwijsorganisatie opgezet met de vakgroepen enerzijds en de discipline overschrijdende onderwijselementen anderzijds.

Een project curriculum werd opgezet met brede ondersteuning waarbij het vaardigheidslaboratorium als eerste gerealiseerd werd. Wij verzuimden dit skillslab in het St. Annadal ziekenhuis te plaatsen; een fout die in de nieuwbouw herhaald is, alhoewel nu de afstand tot de inhoudsdeskundige klinici kort en inpandig geworden is. Reerink en ik maakten een studiereis door Canada en de Verenigde Staten om materiaal voor het vaardigheidsonderwijs bijeen te sprokkelen. Later (1975) werd onder de bezielende leiding van Pie Bartholomeus de training van vaardigheden aan groepjes studenten ter hand genomen. De trainingen in het skillslab vertonen samenhang met de blokperioden en nauwe aansluiting met het kennis-curriculum dat opgebouwd wordt van eenvoudig naar complex en in 1974 met vijftig cursisten gestart werd.

Het is niet mijn bedoeling geschiedschrijving te plegen, maar $U$ allen weet dat ons onderwijs met horten en stoten op gang gekomen is. De pioniersrol had voor- en nadelen. De studenten, toen nog cursisten genoemd, toonden een grote mate van verantwoordelijkheid voor het nieuwe onderwijssysteem, dit was een bron van inspiratie. Vooral in de eerste jaren toonden zij grote betrokkenheid bij het experiment met hun onderwijssysteem. De onderwijstijd bestond van meet af aan voor $20 \%$ uit keuze onderwijs, een wenselijkheid die nu nationaal gevoeld wordt. 
Keuze onderwijs stimuleert de zelfwerkzaamheid en wetenschappelijke keuzen.

Het was zaak, als een der eerste handelingen van het direct na de start in 1976 wegkwijnende decanaat, de onderwijsorganisatie goed op te zetten. Daar in onze instelling de collectieve verantwoordelijkheid op het midden niveau ligt, ontstond een groot Bureau Onderwijs. Toen ik in januari 1978 decaan werd was mijn eerste taak een hoofd Bureau Onderwijs te vinden om het steeds uitgebreider takenpakket aan te kunnen. In de persoon van Bert Kolle is dat gelukt, hij werd van FC Nijmegen overgenomen als een spits met topkwaliteiten. $\mathrm{Nu}$ is Bureau Onderwijs het dienstverlenend en, in nauwe samenwerking met directeur en faculteitsbestuur, bestuderend onderwijscentrum. In het onderwijsverslag 1991 beslaan haar taken enkele pagina's, om deze taken te kunnen vervullen zijn er momenteel vijftien fulltime equivalents. Dankzij Kolle en Steur groeide ons onderwijs en namen de eerste tweeënveertig artsen op 11 juli 1980 succesvol hun bul in ontvangst. Gisteren werd de duizendste artsenbul uitgereikt in de nieuwbouw van de faculteit, de groei en bloei van de medische faculteit illustrerend.

\section{Nieuwe uitdagingen/het Network}

Maastricht werkte voortvarend aan public relations en marketing en de rol van het onderwijs werd steeds intensiever. Aan de World Health Organization (WHO), toen onder leiding van Dr. Mahler, was de Maastrichtse ontwikkeling niet voorbij gegaan. Hij nodigde o.a. McMaster Canada, Beersheva Israël, New Castle Australië en Maastricht in 1978 uit voor een gesprek in Genève. Thomas Fülop was daar de stimulerende coördinator van de intensivering van de nieuwe onderwijsontwikkelingen, vooral in relatie tot de leefgemeenschap (community) waarin zij plaats vond. De opleiding moet kunnen inspelen op de noden en behoeften van een veranderende samenleving. Als artsen weten wij dat ziekte en gezondheid beïnvloed worden door de maatschappelijke context.

In 1979 werd in Jamaica een internationale bijeenkomst georganiseerd door de WHO waarvoor een twintigtal instellingen waarvan de meesten aan modernisering van het medisch onderwijs werkten werden uitgenodigd. Zoals het de WHO betaamt waren daar natuurlijk ook Oostbloklanden bij die de 'community' met zeer traditioneel onderwijs links lieten liggen. Desalniettemin was de bijeenkomst, die namens Maastricht door de rector en onderwijsspecialist Wijnand Wijnen werd bijgewoond een succes. De mogelijkheid tot de oprichting van een Network van probleem gestuurde, op de samenleving ingestelde medische faculteiten werd besproken. Daar een klein land altijd onverdacht is in internationale gezelschappen werd aan Maastricht gevraagd het Network-secretariaat huisvesting te verlenen en de organisatie ter hand te nemen.

Wij zullen even stilstaan bij de betekenis van netwerken. Het werkwoord netwerken betekent verweven met ontwikkelingen, denken, groeien, geven, nemen, reizen, instituties meer zien als een verzameling interessante personen met vaak dezelfde interesses en drijfveren. Een netwerk is het opbouwen, onderhouden en gebruiken van relaties. De kracht van ons Network is dat het vele ideeën, meningen, werkwijzen en gezichten omvat. 


\section{Het Secretariaat}

Het duurde even voordat het secretariaat van het Network in Maastricht op gang kwam. Het was duidelijk dat niet het rectoraat, maar het decanaat van de medische faculteit dit ter hand moest nemen. Ik werd de eerste secretaris-generaal. Wij vonden Ine Kuppen bereid het secretariaat te bezetten en na vele onderhandelingen met de WHO ontstond een Network bestuur waarvan de secretaris-generaal in Maastricht huisde. De statuten, bij notaris Versteeg gemaakt, volgend hebben wij dit secretariaat acht jaar in Maastricht gehad om het vervolgens in 1988 af te staan aan één onzer zusterfaculteiten, Ismailia (Egypte) waar Zohair Nooman nu de secretarisgeneraal is.

Dankzij het basiswerk van Ine Kuppen en Henk Schmidt is het secretariaat zelf in Maastricht gebleven thans bemand door Pauline Vluggen. Het secretariaat kon mede door de financiële steun vanuit het faculteitsbestuur van de medische faculteit in onze handen blijven.

Het Network of Community Oriented Educational Institutions for Health Sciences is uitgegroeid tot een grote internationale paraplu-organisatie waaronder vele innoverende medische faculteiten zich hebben geschaard. Allen hebben zich verplicht volgens het op problemen uit de praktijk gebaseerd onderwijs te werken. De op de gemeenschap gerichte activiteiten zullen voortdurend moeten inspelen op de noden en behoeften van een veranderende samenleving

Sinds de Kingston Jamaica stichtingsbijeenkomst vinden twee jaarlijkse bijeenkomsten plaats. Van de in totaal vijftienhonderd medische faculteiten zijn nu honderdenvijftig faculteiten vol of geassocieerd lid. De bijeenkomsten van de participerende medische en gezondheidswetenschappelijke faculteiten hebben plaatsgevonden in Bellagio Italië in 1981, Havanna Cuba in 1983, Ismailia Egypte in 1985, Pattaya Thailand in 1987, Kerkrade (Rolduc) Nederland in 1989 en Lagos Nigeria in 1991. De volgende bijeenkomst zal, in 1993, plaatsvinden in Sherbrooke Canada. 


\section{De doelstellingen}

De doelstellingen van het Network zijn samengevat in de volgende 5 hoofddoelen.

1. De leden-instituten-versterken hun realisering van het probleem gestuurd onderwijs en hun oriëntatie op de leefgemeenschap waarin zij functioneren.

2. Versterken van de capaciteiten van de individuele faculteiten in relatie tot probleem gestuurd onderwijs en oriëntatie op de gemeenschap.

3. Het ontwikkelen van technologieën, het toegankelijk maken van methodologieën en manier van aanpakken met vaardigheden kennis en training.

4. Bevorderen en ordenen van de op de bevolking gerichte opvattingen van de gezondheidszorgsystemen en onderwijs programma's.

5. Het steun geven aan landen en/of faculteiten die het politieke besluit hebben genomen onderwijsvernieuwingen te introduceren ten behoeve van de training van personeel werkend in de gezondheidszorg.

Een groot aantal workshop-achtige conferenties zijn over de gehele wereld gehouden over diverse onderwerpen zoals, ontwikkeling van het curriculum, de evaluatie van studenten, nieuwe onderwijs methodologieën, op de community gericht onderwijs, vaardigheidstrainingen etc.

De Network activiteiten zijn van groot belang geweest voor de ontwikkeling van een aantal nieuwe medische faculteiten, het ombouwen van bestaande faculteiten en het introduceren van tracks, kleine groepen studenten die naast het traditionele onderwijs volgens de nieuwe principes werken. Dankzij steun aan nog niet ten volle ontwikkelde nieuwe programma's ontstond door de ervaringen van velen een hecht Network. Het WHO-doel deze faculteiten het legitimeringsstempel te geven van een internationale organisatie is goed gelukt. Het co-sponsorschap van de World Health Organization, de Rockefeller Foundation, de Kellogg Foundation en de Macy Foundation hebben daar in belangrijke mate toe bijgedragen. De Network principes werden door de WHO nog eens onderschreven door haar toe te laten als NGO lid (Non Governmental Organizations). De World Federation of Medical Education adopteerde de Network principes zonder de herkomst van deze principes te melden.

In de spirit van de interuniversitaire samenwerking zijn nauwere banden ontstaan tussen groepen medische faculteiten in werelddelen zoals het Midden-Oosten, Egypte en Maastricht en in de westerse hemisfeer, met Columbia, Cuba, Mexico en Canada.

\section{Problemen van het medisch onderwijs in de praktijk}

In grote delen van de wereld zijn problemen met de toegang tot de gezondheidszorg, van de sloppen in de grote steden vooral in de VS tot in rurale gebieden in Pakistan, Mexico, Afrika en Zuid-West Azië. Artsen werken waar kans op privé-praktijk bestaat, hun kinderen onderwezen kunnen worden en de 
woongebieden veilig zijn. In sommige landen verlaten de jonge artsen en verpleegkundigen massaal hun land na de opleiding (Filipijnen $70 \%$ !). Zij worden vooral in ziekenhuizen opgeleid en hebben daarom te weinig kennis voor de praktijk op het platteland bijvoorbeeld. Kerr White toonde al aan dat in academische ziekenhuizen slechts $1 \%$ van het algemeen spectrum van ziekten wordt gezien en in algemene ziekenhuizen $10 \%$.

In het Network moet het onderwijs inspelen op de noden en behoeften van de veranderende samenleving in zijn geheel. Bovendien is duidelijk dat, in tegenstelling tot het traditionele onderwijs, het curriculum van Harvard anders is dan van Bangkok of Khartoum.

In de twaalf jaar van haar bestaan heeft het Network vele nieuwe leden gekregen. Van negentien leden in 1979 tot honderdnegenennegentig in 1992. Het is een hechte groep waar nieuwe strategieën worden uitgeprobeerd. Zo treden meer en meer veranderingen op in traditionele scholen. Het is misschien teleurstellend maar na het afstuderen hebben niet alle studenten invloed op de gezondheidszorg van hun werkgebied. De maatschappelijke ontwikkelingen slijpen soms de Network voordelen er weer af, maar op de lange termijn moet de invloed gaan werken.

\section{De arts van de toekomst}

De golf van veranderingen in het medisch onderwijs is van internationale afmetingen en heeft vele oorzaken. Het is duidelijk dat het traditionele model van medisch onderwijs eenvoudig onvoldoende is om tegemoet te komen aan verwachtingen betreffende de in de toekomst te leveren gezondheidszorg. De arts van de eenentwintigste eeuw zal te maken krijgen met; snelle groei en snelle veroudering van medische kennis en technologie, toenemende specialisatie, verschuiving in ziektebeelden en -oorzaken en toenemende samenwerking van organisaties binnen de gezondheidszorg.

In de huidige informatie decade waarin meer dan 8000 wetenschappelijke artikelen per dag worden geschreven en veel informatie snel obsoleet word tis het onvoldoende 'the state of the art of science' te onderwijzen. Men zal door de bomen het bos niet meer kunnen zien. Daarom moet de arts van de toekomst niet alleen parate kennis worden bijgebracht maar moet hem vooral geleerd worden hoe hij toegang krijgt tot nieuwe informatie, kennis en vaardigheden.

Het ontstaan van het Network was goed getimed en bovendien een noodzaak. Het is een Network van innoverende scholen die ervaringen met elkaar kunnen uitwisselen en elkaars pogingen tot vernieuwing steun en versterking kunnen geven. Maastricht zelf kreeg door haar internationale centrum positie een grote stimulans.

\section{Het PGO systeem}

De arts van de toekomst moet leren hoe te studeren, hoe te selecteren en hoe de eigen verkregen informatie te integreren opdat de beste diagnose en het geschiktste management van de patientenproblemen kan worden bereikt. Het is zorgelijk te zien hoe geneeskunde studenten vandaag nog traditioneel onderwezen worden en als 
huisarts of specialist in de toekomst moeten werken. Het grote collegezaal onderwijs waar men antwoord krijgt op vragen die men zelf nooit gesteld zou hebben is de dominerende vorm van instructie in de pré-klinische jaren. Rogers beschreef het traditionele onderwijs als een drinkpoging van water uit een brandslang.

Door het op problemen gebaseerd onderwijs waarbij niet meer dan tien studenten gezamenlijk werken aan de oplossing van problemen ontstaat peer learning en teaching. Problemen zijn onder meer rond centrale thema's als bloedverlies, kortademigheid en pijn op de borst gegroepeerd. De onderwijsgroepen werken volgens een bepaalde aanpak onder leiding van een zogenaamde tutor. Na een identificatie analyse van de problemen gebaseerd op bestaande kennis worden hypotheses gegenereerd en leerdoelen gezamenlijk opgesteld.

Uit het 'al doende leert men' principe van onze universiteit worden geleidelijk aan elementen overgenomen door de andere, zeer traditionele, onderwijsinstellingen in Nederland.

\section{Vaardigheden}

De fysisch-diagnostische en therapeutische vaardigheden variërend van bloeddruk meten tot hartmassage en van bloed afnemen tot catheteriseren worden in een laboratorium onderwezen. Na bestudering van diaseries, films, video-tapes etc. kan men op fantomen oefenen. Een aantal vaardigheden worden door de studenten op elkaar geoefend, ook wordt veel gebruik gemaakt van simulatiepatiënten die bepaalde ziekten nabootsen. Gesprekstechnieken, het leren opnemen van de anamnese en het omgaan met emoties worden geoefend in het skillslab. Bij de invoering van nieuwe verrichtingen mag alleen bewezen doeltreffendheid maatstaf zijn.

\section{De docent in het PGO}

Tutor en studenten verdelen de leerdoelen voor individuele studies, waarna nieuwe gegevens en kennis in de groep worden uitgewisseld. Hypothese, diagnose en management van de problemen volgt. Vooral het delen van kennis, opinies en ervaringen is een belangrijk leermoment. Al doende leert men de grote hoeveelheid informatie te schiften en wordt men het management van veel informatie meester, steeds met het doel de gegevens te bewerken voor de oplossing van het probleem. Door dit alles ontstaat een organisatie van het geheugen en raakt de student, die zelf bepaalt hoe ver hij gaat in de gegeven tijdspanne, zeer gemotiveerd en volgt zijn/haar eigen voortgang.

Aan de meeste traditionele faculteiten zijn de onderwijsdoelen van een tutorgroep en de grondregels van samenspel zeer wezens vreemd. Docenten feliciteren zich als onderwijzer voor de spiegel in plaats van onderwijsdoelen op te roepen. $\mathrm{Zij}$ motiveren de studenten nauwelijks. In Maastricht is de tutorrol van een ander belang. Een goede tutor moet een voorbeeld zijn voor de studenten, wat betreft hoeveelheid en kwaliteit van de verkregen informatie, kritisch denken, democratie gedurende de sessies, het creëren van enthousiasme en het stimuleren van kennisen procesgroei. De tutor dient een hoge graad van verwachting en prestatie te stimuleren en fasciliteert de gedachten van leiderschap bij de jonge groepsleden. 
Een veelvuldig voorkomende vraag is of een inhoudsdeskundige procesbegeleider nodig is. Ik meen van wel en uit studentenonderzoek van de Volder blijkt dat de inhoudsdeskundige tutor niet alleen zijn rol beter vervult, maar ook beter in staat is fouten te corrigeren. Harvard onderzoek wees uit dat een te dominerende tutor initiatieven van de studenten remt. Ik ben van mening dat de faculteit ernaar moet streven tutoren in blokken in te delen waarvoor deze zich enigszins deskundig achten, student en tutor voelen zich dan minder onzeker. Tijdens de sessies krijgen de studenten zeer veel ervaring in het samenwerken in groepen en het leiden van discussies, zodat de tutor in latere jaren minder actief behoeft te zijn.

\section{Curriculum RL}

In 1974 werd in nauwe samenwerking met de eerste cursisten het curriculum ontwikkeld en tot 1978 met hen samengesteld in een systeem van loven en bieden met ad hoc reacties en correcties en soms het onverwacht geheel omploegen van een onderwijsblok.

De onderwijs discussies liepen soms hoog op. In 1984, tien jaar na het begin van het eerste curriculum, werd de Rode Draad Commissie geïnstalleerd die na lange discussietijd een nieuw curriculum construeerde waarin knelpunten en onvolkomenheden werden weggenomen. Meer aandacht werd besteed aan de altijd moeilijke attitude ontwikkeling en vooral de verwetenschappelijking van de opleiding. De beïnvloeding van artsen door allerlei van kindsbeen af eigen gemaakte gevoelens en geneigdheden, eigen attitude-ontwikkeling, kunnen gehanteerd en gecorrigeerd worden door de eigen houding te expliciteren en bespreekbaar te maken.

Voor nieuwe vakgroepen moet het mogelijk zijn ingang te vinden in het curriculum. De integratie van bijna veertig disciplines en het herhaal niveau zijn van groot belang. Dus, van weinig naar veel integratie met duidelijke herhaalmomenten. Vooral de studenten vragen om een groeiend integratieniveau door de jaren heen, het inbouwen van herhaalmomenten, het goed integreren van de klinische kennis en een duidelijke lijn in de studie. Het curriculum dient mijns inziens iedere vijf a tien jaar te worden gereviseerd.

\section{Kwaliteit}

In Nederland wordt in het onderwijs geleidelijk de gedetailleerde regelgeving door de overheid verminderd en ontstaat een vergroting van de autonomie van de onderwijsinstellingen. Ook binnen de instelling wordt de regelgeving terug gebracht hetgeen leidt tot meer autonomie van de faculteiten. Hierdoor wordt het ons mogelijk gemaakt zelf de inrichting van het te geven onderwijs te regelen en worden wij verplicht zelf zorg te dragen voor de kwaliteit van het onderwijs. Kwaliteitszorg is een taak van de instelling en dus van de faculteiten. De overheid heeft de eindverantwoordelijkheid behouden en vraagt van ons een evaluatiesysteem op basis waarvan de externe verantwoording van de instelling kan worden getoetst, waarbij de kwaliteitsbewaking niet vrijblijvend mag zijn.

De rol van de tutor is er een met een eigen verantwoordelijkheid, het behoort een actieve rol te zijn en men behoort zich op die rol voor te bereiden. Bij- en nascholing 
van de tutor zijn kwaliteitsinstrumenten. De tutor dient in de blokperiode te investeren en systematisch bij de evaluatie van het blok te worden ingeschakeld. De demotivatie van sommige stafleden, ook in de kliniek, is een groot probleem. De kwaliteit van de onderwijsactiviteiten moet bewaakt worden en de bezwaren zoveel mogelijk ondervangen. De motivatie van docenten en het bewaken van hun prestaties is een taak van de faculteit.

De inhoudsdeskundigheid van tutor en staf dient benut te worden in vragenuren of geïntegreerde forums (colleges). Deze momenten kunnen dienen als blokinleiding, integratie van complexe materie, overdracht van nieuwe kennis, uitdiepen van moeilijke onderwerpen, motivatie van student en docent en als vragenperiode na bestudering. Een solistische werkwijze wordt, evenals in het veld, steeds vaker afgewezen. Specialisten gaan meer en meer over tot geformaliseerde samenwerkingsverbanden met toetsing van elkaars handelen en afspraken voor het medisch beleid. Ook huisartsen zullen in grote groepen moeten gaan samenwerken. Dit moet in het onderwijs doorklinken.

In ons onderwijs dient een kwaliteitssysteem te ontstaan met een besturings- en een beheerssysteem. Kwaliteitszorg dient door middel van sterkte-zwakte-analyses bewaakt te worden. Door interne visitaties en evaluaties wordt de kwaliteit gewaarborgd onder leiding van de studierichtingscommissie. De studierichtingscommissie tracht ook een bijdrage te leveren aan de bevordering van de kwaliteit van het onderwijs door het organiseren van facultaire onderwijsdagen. Daar worden thema's besproken die van belang zijn voor de ontwikkelingen in het onderwijs, zoals het functioneren van de onderwijsgroepen, praktisch probleemgestuurd medisch onderwijs en de rol van staf en tutor.

De studentenbijdragen zijn van groot belang voor de kwaliteitsverbetering, zij zijn bij uitstek in staat om vooral de zwakke elementen te signaleren. Studentleden van de studierichtingscommissie, de onderwijscoördinatiecommissie en het agendaberaad zorgen voor deze inbreng. De vakgroep onderwijsontwikkeling en research speelt ook een belangrijke rol in de evaluatie.

\section{Onderzoek}

In het thema 'onderzoek van het onderwijs' komen vragen aan de orde naar de houdbaarheid van onderwijskundige uitgangspunten van ons systeem en de wijze waarop de kwaliteit kan worden verbeterd. Er zijn twee hoofdthema's in het onderzoek: Evaluatie van studieresultaten waarbij het testen van complexe vaardigheden tot en met computer gestuurde kennis en vaardigheden aan de orde komen. Veel onderzoek op de gebieden van vaardigheid en voortgangstoetsen wordt verricht. Het tweede onderzoeksthema is het probleemgestuurd leren met o.a. het effect van de probleemanalyse op het vergaren van individuele kennis. Ook de plaats en de rol van biomedische kennis bij het verwerken van expertise is van belang.

Kwaliteitsnormen worden gesteld en procedures voor meting, uitkomsten en correcties kunnen op basis van onderzoek worden uitgevoerd. Kwaliteitsbewaking vraagt om regels en controle. Voor bepaalde taken zou certificatie verplicht moeten worden zodat de in- en externe toetsing een leidraad heeft. Maar het hebben van een certificaat zal niet betekenen dat er achterover geleund kan worden. Kwaliteit 
bereiken is moeilijk, kwaliteit handhaven nog moeilijker. Onafhankelijk van het hebben van een certificaat is de kwaliteitsmotivatie bij de dagelijkse beslissingen bepalend voor het al dan niet bereiken van de kwaliteit. Wij zullen moeten blijven investeren in de staf, niet alleen voor onderzoek en patiëntenzorg maar ook voor ons onderwijs.

\section{De professionele bureaucratie}

Mintzberg (1979) karakteriseert ziekenhuizen en universiteiten als professionele bureaucratieën. Kenmerkend voor deze instituten is dat de professionele werkzaamheden zijn ingebed in een hiërarchisch (verticaal) georiënteerde administratieve en ondersteunende structuur. De professionals (docenten) zijn voor hun functioneren afhankelijk van de hiërarchische structuur. De relatie tussen de beide organisaties is door hun verschillende aard dikwijls problematisch. Daarom moet er in kwaliteitszorg van professionele bureaucratieën, in dit geval de medische faculteit, aandacht besteed worden aan de volgende zaken:

- coördinatie van onderlinge activiteiten;

- inzichtelijk maken van de werkzaamheden van de professionele kern (in ziekenhuis m.b.v. intercollegiale toetsing);

- afstemming van professionele activiteiten op de omgeving, dit vereist een externe gerichtheid (aandacht voor de wensen en behoeften van de student) en een open oog voor veranderingen in deze omgeving.

De kwaliteit van het medisch onderwijs is goed wanneer het voldoet aan de eisen van de omgeving en het veranderende beeld van de arts. De medische faculteiten dienen hun studenten op te leiden voor de toekomst en niet voor het heden.

Wil men de kwaliteit van het onderwijs verbeteren dan zal men deze moeten meten. Volgens de moderne bedrijfskundige aanpak vestigt een indicator ( $=$ het meetbare element) de aandacht op onderdelen van het onderwijs en op de organisatie hiervan die nader geëvalueerd kan worden. Dat wil zeggen dat een indicator bij overschrijding van een zekere drempelwaarde een probleem oplossend proces op gang moet kunnen brengen. Om zo'n proces op gang te brengen moet uiteraard wel duidelijk zijn naar welk aspect van het onderwijs de indicator verwijst en wie er actie moet ondernemen. Moderne kwaliteitssystemen zijn managementinstrumenten die top down moeten werken maar er dient ook een studenten feedback te zijn. De faculteit dient systematische informatie over de voortgang van de student te vergaren (bottom up). Wij kunnen veel leren van de bedrijfskundige kennis en technieken op het gebied van kwaliteitsbewaking en -verbetering.

\section{Accreditering}

In navolging van de VS, waar men als gevolg van een explosieve groei van het aantal instellingen met steeds grote differentiatie steeds objectiever is gaan normeren, is men ook in Nederland gekomen tot spelregels tot het behoud van academische normen. In de jaren veertig is vooral in de medische sector een systeem van door vakgenoten uitgevoerde institutionele beoordeling en evaluatie ontstaan bekend als accreditering. Het accrediteringssysteem heeft een uitstekende 
ontwikkeling doorgemaakt met verfijning van de normen.

Ook in Nederland heeft de accreditatie van medische deel- en vakopleidingen na de Tweede Wereldoorlog een grote vlucht genomen. In de loop der tijden is een aantal vooraf geformuleerde normen opgesteld. Een visitatieteam, bestaande uit hiervoor door ervaring getrainde vakgenoten en studenten afkomstig van instellingen die door de gevisiteerde instellingen niet als direct concurrerend wordt ervaren (buiten regionale teams), beoordeelt faculteiten op basis van de vastgestelde normen. Een nationale commissie (in Nederland) bestaande uit voor het specialisme representatieve docenten, bestuurders en studenten neemt een beslissing op basis van de gegevens die mede gebaseerd is op een zelfrapportage tegen het licht van de visitatienormen. Het stellen van sancties dan wel het scheppen van verwachtingen met betrekking tot aanbevolen verbeteringen behoort tot de mogelijkheden. Ook in ons onderwijs en in onze instellingen dient een kwaliteitsgarantie te worden geboden.

Vroeg of laat dient zich in het kader van de Europese vertakkingen de vraag aan naar een Europese standaard in termen van eindtermen en kwaliteit van universitaire opleidingen. Een sterkere Europese concurrentie zal zich laten gelden. De Europese kwaliteitsnorm zal medebepalend worden voor de concurrentiepositie van de afgestudeerden aan Nederlandse universiteiten op de Europese arbeidsmarkt. Het is dus waarschijnlijk dat accrediteringscommissies het onderwijs in de toekomst internationaal zullen beoordelen en erkennen. Daarom is internationale vergelijkbaarheid van Nederlandse universiteiten een noodzakelijk toekomstperspectief.

\section{De toekomst van het Network}

Het Network heeft als nieuw doel onderwijsinstellingen te stimuleren en te ondersteunen bij de evaluatie en het verbeteren van de kwaliteit van het onderwijs. Men gaat hiertoe minimum eisen overeenkomen in die zin dat ook de kwaliteit van het onderwijs van de lid-instellingen overeenkomt. Het is duidelijk dat willen de universiteiten en hun faculteiten in de huidige competitie stand houden er constante kwaliteitstoetsing zal moeten plaatsvinden. Het proces dient de onderwijskundige doelen te omschrijven met zelfstudies en toegespitst te worden op deze doelen. Collegae vakgenoten dienen een evaluatie uit te voeren om tot erkenning te komen. Door dit proces en deze status bewerkstelligt men controle en kwaliteitsverbetering door het verder ontwikkelen van criteria en richtlijnen die de effectiviteit van het onderwijs dienen. Continue zelfstudie en evaluatie dienen dan ook door de instellingen ter hand te worden genomen.

In het Network gelden deze principes ook en wordt kwaliteitszorg nagestreefd door advies en ondersteuning in bestaande en zich ontwikkelende onderwijsinstellingen. Bovendien biedt het Network bescherming tegen elementen die de effectiviteit van het onderwijs of de academische vrijheid kunnen aantasten.

\section{Hoe te evalueren?}

Steeds meer instituten ontwerpen een zelf geïnitieerde evaluatie met zelfrapportage. Soms worden bij dit proces personen van buiten de instelling betrokken die 
optreden als adviseur dan wel evaluator, zodat na een proefevaluatie de erkenning snel kan verlopen. Bovendien kunnen de opbrengsten van het proces voor het verbeteren van de eigen doelen worden gebruikt.

In Europees verband ligt regionale evaluatie (Benelux) voor de hand, bij verdere internationalisatie zullen regionale accrediteringscommissies ontstaan. Onverlet blijft de noodzaak van ieder land zijn eigen beoordelingssysteem te organiseren waarbij een meer en meer grondige beoordeling ontstaat; zoals eerder gezegd wordt vooral in de VS veel nadruk op dit erkenningenbeleid gelegd.

Uiteraard kan dit alles ook plaatsvinden op het niveau van studierichting en vakgebied. Vaak zijn deze erkenningen complementair, ze dienen in een kwaliteitssysteem meer en meer geïntegreerd te worden op instellingsniveau. Een probleem blijft de lage universitaire status van het onderwijs, de beoordeling van promoties gaat meer op basis van onderzoekprestaties en patiëntenzorg.

\section{Evaluatie bij de RL}

De RL is opgericht in de tijd van de oliecrisis, hierdoor was het noodzakelijk over de effectiviteit van ons functioneren na te denken. Bovendien bestond er gezien de opzet van onderwijs en onderzoek een toenemende behoefte een interdisciplinair contact met op de praktijk gerichte vraagstukken. Eén ervan was, 'hoe integreren we de student in de organisatie?'. Wat de beoordeling van studieresultaten betreft bestaan er twee systemen naast elkaar. De bloktoets informeert over de studieprestatie per blok. De zogenaamde voortgangstoets informeert over de voortgang van de student over het geheel. De toetsing is gebaseerd op wat de student als basisarts behoort te weten en meet periodiek vier keer per jaar hoe ver $\mathrm{hij} / \mathrm{zij}$ op die weg gevorderd is.

In het onderzoek van het onderwijssysteem komen vragen aan de orde naar de houdbaarheid van de onderwijskundige meetpunten, hoe het onderwijs is te optimaliseren, de rol van voorkennis en motivatie bij de analyse van problemen, hoe formuleren de onderwijsgroepen de leerdoelen op grond van de gepresenteerde problemen, wat is de rol van de tutor en welke leeractiviteiten zijn er. Zo worden ook nieuwe evaluatienormen zoals de voortgangstoets tegen het licht gehouden en wordt de handhaving van Maastrichtse medici in hun beroep vergeleken met elders opgeleiden.

Met behulp van bedrijfskundige principes van kwaliteitsbewaking en -verbetering kan de medische faculteit in Maastricht haar toonaangevende positie behouden, zij leidt reeds jaren artsen op voor de eenentwintigste eeuw. 


\section{Bedankt}

Mijnheer de Rector Magnificus,

aan het eind gekomen van mijn afscheidsrede sta ik voor de onmogelijke opgave alle personen te bedanken die mij in de nu bijna twintig jaren Maastricht ter zijde hebben gestaan in het organiseren van een vooraanstaand chirurgisch instituut en het realiseren van een medische faculteit met internationale uitstraling. Voor twee groepen wil ik toch een uitzondering maken. Als eerste onze studenten. Zij blijven de bron van onze inspiratie en velen zijn speciaal naar Maastricht gekomen daar zij wisten dat het probleem gestuurd onderwijs door de integratie van theorie en praktijk en door de intensieve vaardigheidstraining hen goed voorbereidt op de toekomst. De college gevende docent is van zijn sokkel gelicht en de accenten in Maastricht liggen op het groepsfunctioneren en de zelfwerkzaamheid.

Daar de arts steeds minder als solist fungeert, en steeds meer contact moet onderhouden en besprekingen zal voeren met collegae en andere werkers in de gezondheidszorg, is de opleiding ideaal voor dit doel. De beschikbare opleidingstijd maakt het de faculteit onmogelijk meer dan een globaal inzicht te bieden in de veertig vakgebieden. Artsen die vandaag de universiteit verlaten lopen over een jaar al achter bij de stand van zaken in de wetenschap. De arts van de toekomst zal naast een zekere hoeveelheid basiskennis moeten leren hoe hij zelfstandig medische problemen oplost en hoe hij op een efficiënte manier toegang krijgt tot nieuwe kennis en vaardigheden.

In Maastricht kunt $U$ dit leren maar onze inspanningen scheppen verplichtingen van beide kanten. De faculteit dient een contract met $U$ te sluiten waarin beide partijen een inspanningsverplichting leveren opdat $U w$ studie in de fraaie gebouwencomplexen vlot en niet in het minst goed kan verlopen.

Door het verkorten van het recht op studiefinanciering tot vijf jaar en het invoeren van een zogenaamde tempobeurs wordt de druk op $U$ om zo snel mogelijk af te studeren groter. Belangrijk blijft dat $U$ zich naast $U w$ studie maatschappelijk ontwikkelt, het maakt onderdeel uit van de academische vorming. 
Dames en Heren,

Last but not least faculteit en ziekenhuis, beiden hebben mij praktisch altijd gesteund. Het afscheid van het ziekenhuis was een hoogtepunt, universiteit en faculteit blijven niet achter. Het was een enorm voorrecht hier te mogen werken. Toen Slater mij destijds, in 1973, adviseerde de baan te aanvaarden had ik geen idee dat de toekomst er zo uit zou zien.

Mijn oprechte dankbaarheid gaat uit naar allen, vooral naar de teamgenoten van faculteit, Network en vakgroep. Ik heb steeds getracht de beste medewerkers in het land aan te trekken en heb het voorrecht gehad deze te vinden. Klinisch en wetenschappelijk is de algemene heelkunde in Maastricht tot grote bloei gebracht. Mijn dankbaarheid gaat uit naar hen in de Garoedaclub of nog steeds in Maastricht verblijvend. Jullie hebben mij veel vrijheid gelaten en dankzij jullie inzet is de vakgroep een begrip geworden in het land. Zowel klinisch als wetenschappelijk een centrum van bruisende activiteiten. Mijn opvolger in de persoon van de onvolprezen Kootstra is goed geregeld. Ik wens jullie een goede vaart, het schip ligt op koers, houdt de heelkundige eenheid, bescherm de segmenten en Maastricht zal toonaangevend blijven.

Zoals $\mathrm{U}$ begrijpt is mijn loopbaan niet afgelopen mar het einde hier is in zicht.

Het gaat U goed. 
Literatuur

Bureau Onderwijs Faculteit der Geneeskunde. Zelfstudie geneeskunde 1991. Maastricht. Juli 1991.

Casparie, A.F., Harteloh, P.P.M., et al. Kwaliteit van zorg: van een zorginhoudelijke benadering naar een bedrijfskundige aanpak. 's-Gravenhage: VUGA, 1991.

Cohen, M.J., Luttikholt, H.W. De Europese Gemeenschap als nieuwe actor binnen het Hoger Onderwijs in: $U$ \& $\mathrm{H}$, Tijdschrift voor wetenschappelijk onderwijs. 5(1992): 246-252.

Fekkers, H., Messing, B., et al. (red.). Wetenschappelijk Jaarverslag Rijksuniversiteit Limburg 1990. Uniprint.

Kaufman, A. (red.). Implementing Problem-Based Medical Education: Lessons from Successful Innovations. New York: Springer Publishing Company, 1985.

Muller, S. (Chairman). Physicians for the Twenty-First Century. Report of the Project Panel on the General Professional Education of the Physician and College Preparation for Medicine. Journal of Medical Education. 59, part 2, November 1984.

Neufeld, V.R., Woodward, C.A., MacLeod, S.M. The McMaster M.D. Program: A Case Stydy of Renewal in Medical Education. Acad. Med. 65(1990): 423-432.

Nieuwenhuijzen, A.C., Kruseman, Sanders, H.W.A. Evenwicht in Maastricht; Een stimulans voor zelfwerkzaamheid. Medisch Contact. 35(1992): 982-986.

Nooman, Z., Schmidt, H.G., Ezzat, E. (red.). Innovation in Medical Education. An Evaluation of its Present Status. New York: Springer Publishing Company, 1990.

Richard, R., et al. Innovative Schools for Health Personnel: Report on Ten Schools Belonging to the Network of Community-Oriented Educational Institutions for Health Sciences. WHO Technical Report Series. Geneva, Switzerland: World Health Organization, 1987.

Schmidt, H.G., De Volder, M.L. (red.). Tutorials in Problem-Based Learning. Assen, The Netherlands: Van Gorcum, 1984.

Schmidt, H.G., Lipkin, M., De Vries, M., Greep, J.M. (red.). New Directions for Medical Education. New York: Springer Verlag, 1989.

World Fedaration for Medical Education. The Edinburgh Declaration. Annual Community-Oriented Education. 2(1989): 111-113. 


\section{IEDER DETAIL TELT}

Afscheidsrede Prof.Dr. J.M. Greep, hoogleraar chirurgie Academisch Ziekenhuis Maastricht

27 maart 1992 
22 
Mijnheer de voorzitter van de raad van bestuur, Mijnheer de voorzitter van de raad van toezicht, Hooggeleerde Kootstra,

Dames en heren,

Met mijn afscheid van de vakgroep Algemene Heelkunde sluit ik een periode van meer dan veertig jaar chirurgie af.

$\mathrm{Nu}$ precies eenenveertig jaar geleden werd ik in het Bethel Ziekenhuis te Delft voor een acute appendicites opgenomen. De chirurg Dr. Evert Verschuyl vroeg mij de tweede dag postoperatief in de operatiekamer te komen assisteren - ik was toen vierde jaars geneeskunde student. Sinds die tijd heb ik met hem en zijn zoon Arnold Verschuyl mogen meewerken in de boeiende Bethel/Hyppolitus praktijk van Verschuyl die mij al vroeg leerde dat ieder detail telt. Er waren in Delft vele hoogtepunten, zo voerden wij als een der eersten een peritoneaal dialyse uit en verrichtten wij een maal per week grote long chirurgie in het Emmapaviljoen, een tuberculose sanatorium te Zevenaar aan de Duitse grens.

Onze eerste drie publikaties verschenen voor het artsexamen in 1956. Toen ik in 1956 in het toenmalige Coolsingel Ziekenhuis te Rotterdam bij Dr. van Staveren mijn opleiding begon, had ik een vliegende start. Van hem heb ik geleerd dat de patiënt het centrum van ons handelen dient te zijn en dat wij er alles aan moeten doen om in de beste conditie en met de hoogste concentratie iedere operatie te kunnen uitvoeren. Technisch verrichtte hij wonderen. Alhoewel wij jarenlang om de nacht dienst deden kon ik dankzij hulp van velen in 1958 promoveren op het proefschrift 'Antithrombine en aandoeningen van het Pancreas'. De internist Prof. Hulst in Utrecht was de promotor en Loeliger uit Leiden mijn steun.

\section{Loopbaan}

$\mathrm{Na}$ en door de tweede wereldoorlog was een indrukwekkend medisch-technisch arsenaal ontstaan, zowel medisch-biologisch als klinisch. De algemene heelkunde begon in de vijftiger jaren aan een bloeiperiode. Ik had het voorrecht deze bloeiperiode in Harvard Medical School en het Massachusettes General Hospital mee te maken. Op basis van mijn dissertatie, uitgenodigd door George Nardi (1960), werd ik door de Varkensbaai invasie, door de staf gevraagd in the House Staff te functioneren. Deze drie jaren waren onvergetelijk. De enorme chirurgische staf, de open discussietrant, het gedetailleerd bespreken van complicaties, de vriendschap der maten in opleiding en het 'management by objectives' waren ervaringen die in de Nederlandse, om één man gebouwde hiërarchische structuur, ondenkbaar waren. Het is goed dat vele jonge chirurgen daarna Boston en andere centra in de Verenigde Staten op soortgelijke wijze hebben bezocht. Ik heb er altijd een punt van gemaakt een ieder deze gelegenheid te bieden. De Nederlandse heelkunde is verrijkt door deze ervaringen en de blijvende contacten.

Wij waren in Boston in de periode dat de bomen tot de hemel leken te groeien. Orgaantransplantaties werden geïntroduceerd, vele nieuwe technieken ingevoerd en verfijnd. De eerste arm werd succesvol weer angenaaid, wij isoleerden de alvleesklier en konden uren de patho-fysiologie van het geïsoleerde orgaan 
bestuderen.

Ik keerde in 1964 terug naar het Dijkzigt Ziekenhuis te Rotterdam als chef de clinique heelkunde in de periode dat zich over de gehele wereld een enorme bloei van de chirurgie ontwikkelde. In Dijkzigt introduceerde ik de experimentele chirurgie en de vaatchirurgie.

In 1966 vroeg Brummelkamp mij met hem in het Sint Lucas Ziekenhuis (een geheel nieuw ziekenhuis in Amsterdam-West) een praktijk op te starten. Het openingssymposium, bijgewoond door 1400 gasten, heette; 'Organtransplantation today'. Ze waren er allemaal van Starzl tot Van Rood en van Calne tot Barnard.

\section{Ontwikkeling van techniek en kosten}

Het was een voorrecht betrokken te zijn bij de vele ontwikkelingen; het medisch technisch arsenaal bleef zich verruimen. Computer, geluids- en magnetische golven, endoscopische en laparoscopische technieken ondersteunen nu diagnostiek en behandeling. Met name de echografie en endoscopie, maar vooral de intensieve zorg, werden in de algemene heelkunde geïntroduceerd. Nieuwe technologische ontwikkelingen hebben geleid tot sterke uitbreiding van de diagnostische verrichtingen.

\section{Medische dienstverlening}

Door deze ontwikkelingen en het groeiend stelsel van sociale voorzieningen breidde de medische dienstverlening zich enorm uit. Van 3\% van het B.N.P. in 1953 (het eerste jaar waarvan statistische gegevens verzameld zijn) tot $9 \%$ nu, of wel van 770 miljoen gulden toen tot 52,6 miljard gulden verwacht in 1992; het zeventigvoudige. Dit heeft grote gevolgen gehad voor zowel de geneeskunde als de wetenschap, alsook voor de structuur en de kosten van de gezondheidszorg. De permanente volume overschrijding creëert financiële problemen waardoor onze verzorgingsstaat in gevaar komt.

Patiënt en arts hebben door hun gedrag deze kosten sterk laten stijgen. De patiënt/consument verwacht in onze welvaartsstaat een onbelemmerde toegang tot de gezondheidszorgvoorzieningen. Het grondwettelijk recht op gezondheidszorg wordt met behulp van patiëntenverenigingen erkend en men maakt aanspraak op volledige realisering ervan. Vele huisartsen die aarzelen door te verwijzen ondervinden letterlijk de krachtige wens hiertoe van de patiënt. Ook de grenzen van de welvaart zijn overschreden. Het arbeidsverzuim is hoog (11\%), meer dan $12 \%$ van de beroepsbevolking heeft een WAO uitkering; er zijn nu 900.000 arbeidsongeschikten waarvan $85 \%$ in de hoogste arbeidsongeschiktheidsklasse. Dankzij of ondanks deze dure verwordingen heeft Nederland de hoogste arbeidsproduktiviteit ter wereld.

Uit de toekomstscenario's, ik heb het voorrecht hierbij van meet af aan betrokken te zijn geweest, is alarm geslagen over de toekomst van de gezondheid van de snel verouderende bevolking. Vooral het aantal kanker- en ongevalspatiënten en het aantal chronisch zieken onder ouderen blijft toenemen ( $3 \%$ per jaar). Ook de gevolgen van riskant leefgedrag dienen zich aan. Zo neemt longkanker door overdadig roken epidemische vormen aan; 7.500 doden per jaar. Alcohol- en 
druggebruik nemen toe.

Artsen hebben door de exclusiviteit van hun verantwoordelijkheid en hun drang naar perfectie de kwaliteit van zorg sterk verbeterd, maar hierdoor de kosten opgevoerd. Op een of andere manier moeten wij deze kosten bedwingen. Tal van oplossingen en mogelijkheden dienen zich aan: beddenreductie, budgettering, privatisering, stelselwijziging volgens Simons, opkomst van de goedkopere thuiszorg, protocolaire geneeskunde en meer aandacht voor preventie. Maar welke weg leidt daadwerkelijk naar kostenbeheersing met behoud van kwaliteit?

\section{Onderwijs van de toekomst}

De moderne geneeskunde is door verwachting en verwijzingen ondanks vergaande specialisatie in de ziekenhuizen geworden tot een integrale geneeskunde, een trend waaraan in het medisch onderwijs in Maastricht veel aandacht wordt besteed. Toen de achtste medische faculteit naar Maastricht kwam zijn wij direct gestart met het Probleem Gestuurd Onderwijs naar voorbeeld van de Mc Master Medical School. De college gevende docent werd van zijn sokkel gelicht en het accent kwam te liggen op zelfwerkzaamheid. Vanaf het begin wordt de RL-student op vaardigheden getraind in het skillslab en wordt veel tijd besteed aan de integratie van theorie en praktijk. Ook sociale vaardigheden en attitude training vormen een belangrijk onderdeel van de Maastrichtse opleiding. De student bestudeert aan de hand van de meest voorkomende klachten en problemen de theorie der afzonderlijke vakgebieden en integreert deze bevindingen in groepsdiscussies.

Een belangrijke rol hierbij speelt ook de voortgang op gebieden van communicatie en informatieverwerking, in de praktijk gebracht in de AV-ruimtes van de instelling. De arts kan steeds minder als solist fungeren, hij dient in teams te werken en zal veel contact moeten onderhouden en besprekingen voeren met collega's en andere werkers in de gezondheidszorg.

Al deze veranderingen en de snelle ontwikkelingen in de medische wetenschap vereisen een andere opleiding dan toen ik vierenveertig jaar geleden Leiden binnen trad. De beschikbare opleidingstijd maakt het de medische faculteiten onmogelijk om studenten meer dan een globaal inzicht te bieden. Artsen die vandaag de universiteit verlaten lopen over een jaar al achter op de stand van zaken in de wetenschap. Consequentie is dat naast een zekere hoeveelheid basiskennis de toekomstige arts zal moeten leren hoe hij zelfstandig medische problemen oplost en hoe hij op een efficiënte manier toegang krijgt tot nieuwe kennis en vaardigheden. In de opleiding van de eenentwintigste eeuw met veel aandacht voor de training van vaardigheden, komt het misschien zelfs zover dat artsen leren opereren met behulp van een simulator; de zogenaamde 'video-simulator-chirurgie'. Dit idee is vergelijkbaar met de opleiding tot piloot. De piloten in spé oefenen in een simulator en pas wanneer zij hun diploma hebben gaan zij voor de eerste keer het luchtruim in.

\section{Keuzen}

Bezorgdheid over de economische effecten van de proliferatie der geneeskunde is op haar plaats. In de geneeskunde van de westerse wereld geldt de wet van de 
afnemende meeropbrengst. De marginale verbeteringen in de complexe hulpverlening gaan gepaard met sterk toenemende kosten.

In 1990 installeerde Simons een commissie die in november 1991 advies heeft uitgebracht over keuzen in de zorg. De commissie 'Keuzen in de Zorg', onder voorzitterschap van de cardioloog Dunning, kreeg tevens de opdracht mee om een publieke discussie op gang te brengen over de vraag: Moet alles wel wat kan?. De commissie Dunning heeft een zeer generalistisch trechtermodel gepresenteerd. Maar ieder individu is anders en leeft onder andere omstandigheden, de commissie Dunning gaat mijns inziens 'een brug te ver' door alles en iedereen door dezelfde zeef te gooien.

Het rapport 'Medisch handelen op een Tweesprong' vind ik aanmerkelijk beter. Enkele aanbevelingen uit dit rapport zijn:

- effectiviteits- en kwaliteitsonderzoek moet uitgroeien tot een activiteit die door artsen wordt uitgevoerd,

- de artsen-opleiding moet praktijk gerichter worden,

- voor het invoeren van nieuwe verrichtingen dient het 'gebruikelijkheidscriterium' te worden afgeschaft.

Door artsen groeperingen zullen praktijkomvang, menskracht, planning, vestigingsbeleid, maatschap uitbreiding en dienstplanning beter ter hand moeten worden genomen. Bij overdracht van patiënten ontstaan te veel complicaties door een gebrek aan goede communicatie. Veel inzicht en visie zal nodig zijn om het door politici teruggedrongen aantal werkuren te benutten. Middelen en tijd dienen efficiënter te worden gebruikt. Er zullen keuzes gemaakt moeten worden in de zorg. Door artsen zal in de toekomst weloverwogen en per individu gekozen gaan worden. Alle operaties en behandelingen uitvoeren kan nu eenmaal niet meer. Het ideaal van de welvaartsstaat zal moeten worden losgelaten. De samenleving wordt als het ware zelf het slachtoffer van de vooruitgang in de techniek. Bovendien zijn management- en bedrijfskunde-opleidingen in het leven geroepen om dit effect te bestuderen.

\section{Ieder detail telt}

Het recente gejuich van de voorzitter van de LAD (Landelijke vereniging van Artsen in Dienstverband) over een 48-urige werkweek voor artsen in opleiding zal verstommen als de echte rekening in de vorm van fouten en patiëntencomplicaties zal worden gepresenteerd.

leder detail telt in de gezondheidszorg en vooral in de chirurgie. De verouderende mens is toenemend een occasion met vele potentiële problemen, zeker bij acute en electieve chirurgie. De behandelende artsen dienen diepgaande kennis te hebben van alle patiëntenproblemen.

Ook voor de jonge chirurg van de toekomst telt ieder detail; observeren, luisteren, onderzoeken voor, tijdens en na operaties moet een onderdeel van het dagelijks functioneren worden. Veel overlegtijd is nodig en in steeds kortere tijd dient een groot aantal vaardigheden te worden getraind. De opleidingstijd zal mede door de verdere Europanisatie worden teruggedrongen. Behalve de huisartsenopleiding; nu 
deze eindelijk wordt verlengd van twee naar drie jaar eist de Europese Commissie dat de totale specialisatie niet langer dan zes jaar mag duren.

In de Verenigde Staten en in Japan duurt de algemeen chirurgische opleiding vijf jaar, voor vervolgopleidingen wordt 1 jaar uitgetrokken. De Nederlandse opleiding moet dus ondanks vele uren per week minder, ook terug in totaaltijd en de vervolgopleidingen zullen over hun opleidingstijd moeten discussiëren. In de VS en Japan is de werktijd lang (60-70 uur per week). In Engeland werd recent tijdens onze werktijd discussie besloten het aantal weekuren voor artsen in opleiding van teeëntachtig in 1991 naar uiteindelijk drieënzeventig in 1994 terug te brengen. In het Nederland van workaholic Lubbers en zuinigmondje De Vries werd ons achtenveertig uur opgedrongen in plaats van de ook door arts-assistenten gewenste zestig uur. Kennis, tijd en overdracht spelen een grote rol binnen de opleiding, daar is tijd voor nodig. Wij moeten er voor waken dat we in Nederland met onze (te korte) opleiding niet als een hobbelpaard stil blijven staan in de race met echte paarden en zo een enorme achterstand krijgen op andere landen. De vereniging voor heelkunde heeft een dramatisch pleidooi gehouden voor een 60-urige opleidingsweek, maar Brutus Levi heeft gesproken. Hij mag extra blij zijn dat ik vandaag afscheid neem.

\section{De chirurgische opleiding}

In Nederland is het Concilium Chirurgicum verantwoordelijk voor de chirurgische opleiding. Daar de gehele opleiding hieronder valt dient de nieuwe bestuursstructuur van de Nederlandse Vereniging voor Heelkunde te worden overgenomen door ook in het Concillium een vertegenwoordiger per subvereniging op te nemen. Het moederspecialisme Algemene Heelkunde heeft de deelgebieden ook voor de opleidingen dan in gezamenlijkheid bijeen.

De opleiding tot algemeen chirurg blijft in beweging. Ook in de nieuwe tijdsplanning blijft het algemene deel twee tot drie jaar in de perifere ziekenhuizen. Door fusies ontstaan grotere perifere ziekenhuizen waardoor men over een groot aanbod van patiënten kan beschikken. In de academische centra zal de opleiding moeten worden vervolmaakt. De gespecialiseerde opleidingen zullen er ook plaats moeten vinden naast de instruktie in enkele hoog gespecialiseerde niet-academische ziekenhuizen.

De tijd voor wetenschappelijk werk moet in het voortraject direct na de medische studie worden gevonden, AIO-schappen en AIO-AGIO overgangen moeten hier gecreëerd worden. Het belang van de gecombineerde AIO/AGIO (AGIKO) opleiding voor de ontwikkeling, kwaliteit en continuïteit van het klinisch patiëntenonderzoek is groot.

Een goede samenwerking tussen medische faculteit en academisch ziekenhuis is een voorwaarde voor een gedegen opleiding. In Maastricht is deze samenwerking met de opening van het nieuwe academisch ziekenhuis begin 1991, naast het faculteitsgebouw, alleen maar beter geworden. De gebouwen horen bij elkaar, we hebben een agora gecreëerd, een workshop waar patiënt en dokter, docent en student, verpleegster en bezoeker elkaar kunnen ontmoeten. Het is één geheel. 


\section{Privatisering}

Sinds enige tijd is het verschijnsel privé-klinieken weer een actueel onderwerp van discussie. De eerste kliniek van Boerema was een opblaasbootje dat al gauw werd lek gestoken; hij kwam te vroeg met zijn innovatieve ideeën. Nu is duidelijk dat de privatisering van de gezondheidszorg zal doorzetten. Privé-klinieken en villageneeskunde zijn langzamerhand bekeride fenomenen, er is zelfs een instituut opgericht dat klinieken die aan bepaalde (kwaliteits)eisen voldoen erkent. Volgens staatssecretaris van WVC de heer Simons passen zij uitstekend in het nieuwe verzekeringssysteem zoals dat (misschien) wordt ingevoerd. Met betrekking tot kwaliteit en bereikbaarheid is de grootste voorzichtigheid vereist. De klinieken zullen duidelijke afspraken moeten maken met bestaande voorzieningen. $\mathrm{Zij}$ zullen een samenwerking moeten aangaan met de instellingen om de kwaliteit van zorg te kunnen waarborgen en om eventuele complicaties te kunnen opvangen, want ook hier geldt; ieder detail telt.

Teikyo Medical Centre is zo'n samenwerking aangegaan met het Academisch Ziekenhuis Maastricht. Het AZM levert gedeeltelijk het personeel voor TMC. Zonder zo'n structuur is het onmogelijk en onverantwoord privé-klinieken toe te laten in de kwalitatief uitstekende Nederlandse gezondheidszorg.

Ook voor het ziekenhuis in de Portugese Algarve kunnen we nu eindelijk aan opstarten gaan denken. Na jaren van onderhandelen en keihard werken lijkt de financiering rond te zijn.

\section{De stelselwijziging}

Ik wil deze afscheidslezing afsluiten met enkele woorden over de op stapel staande en gedeeltelijk reeds ingevoerde stelselwijziging. Het gaat mij zeer aan het hart dat de gezondheidszorg warin ik reeds veertig jaar met heel veel plezier heb mogen werken, door een stelletje bureaucraten wordt omgegooid. Wat kunnen we verwachten van een nationale volksverzekering met enkele marktelementen? Kostenproblemen door volumestijging, kartelvorming die het marktprincipe ondermijnt, een te groot basispakket zodat er geen incentives voor de consument zijn, een onbegrensde zorgvraag, vrije artsenkeuze staat onder spanning, kwaliteit is in gedrang door prijsconcurrentie, continuïteit van opleiding is in gevaar etc.

I $k$ ben met vele anderen bang voor Amerikaanse praktijken. De volgende fase, het onderbrengen van de huisarts in de AWBZ per 1 januari 1993 is deze week gelukkig afgeblazen.

Het huidige systeem, één van de beste ter wereld, kan met wat aanpassingen en minder overhoop halen uitstekend functioneren. Het is niet verantwoord het roer in één klap om te gooien. De logge olietanker warmee de Nederlandse gezondheidszorg vergeleken kan worden, zal ten onder gaan bij het nemen van te scherpe bochten. Dit moet voor alles vermeden worden.

\section{Afscheid nemen}

U begrijpt dat ik nog uren kan doorpraten over de chirurgie en de gezondheidszorg in het algemeen. Maar het is onmogelijk om in een klein half uur veertig jaar 
functioneren in de medische wereld weer te geven.

Het einde nadert en kan niet langer worden uitgesteld. Het is een onmogelijke opgave, en u zult dat billijken, om alle personen te bedanken die mij veertig jaar ter zijde hebben gestaan. In het organiseren van een vooraanstaand chirurgisch instituut en het realiseren van de medische faculteit.

Ik zou in één persoon mijn dank willen symboliseren. Dit is uiteraard mijn vrouw Nel, die mij op onnavolgbare wijze heeft begeleid, gecorrigeerd, afgeremd en sporadisch heeft aangemoedigd. Nel bedankt.

Allen bedankt voor de fantastische jaren en dit werkelijk ongekende afscheid. Ik heb gezegd. 


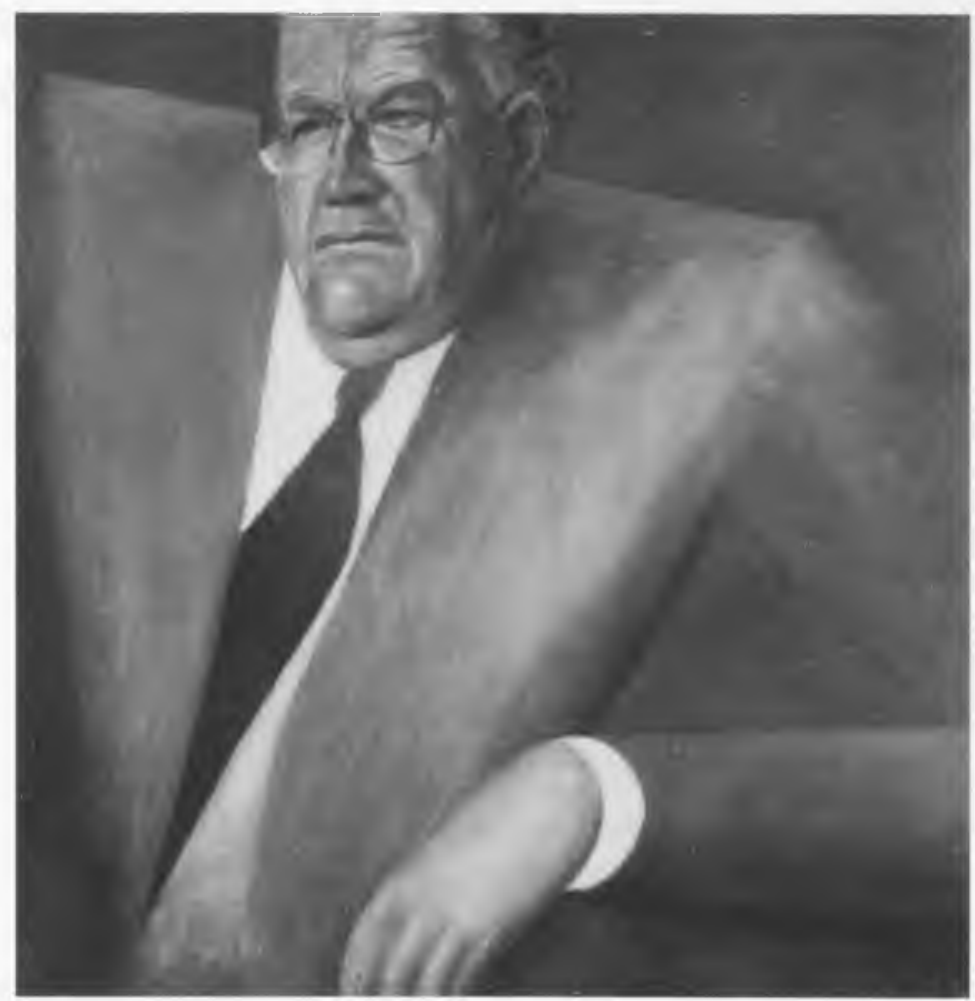

Geschilderd portret door Ger Boosten, aangeboden door het College van Bestuur aan de Medische Faculteit 